\title{
OPEN Biochemical and structural characterization of a recombinant fibrinogen-related lectin from Penaeus monodon
}

\author{
Nongnuch Singrang ${ }^{1,2}$, Sirasit Laophetsakunchai ${ }^{1}$, Bich Ngoc $\operatorname{Tran}^{3}$, Paul T. Matsudaira ${ }^{3}$, \\ Anchalee Tassanakajon ${ }^{1} \&$ Kittikhun Wangkanont $^{1,2 \varpi}$
}

Fibrinogen-related lectins are carbohydrate-binding proteins of the innate immune system that recognize glycan structures on microbial surfaces. These innate immune lectins are crucial for invertebrates as they do not rely on adaptive immunity for pathogen clearance. Here, we characterize a recombinant fibrinogen-related lectin PmFREP from the black tiger shrimp Penaeus monodon expressed in the Trichoplusia ni insect cell. Electron microscopy and cross-linking experiments revealed that $P m$ FREP is a disulfide-linked dimer of pentamers distinct from other fibrinogenrelated lectins. The full-length protein binds $\mathrm{N}$-acetyl sugars in a $\mathrm{Ca}^{2+}$ ion-independent manner. $P m$ FREP recognized and agglutinated $P$ seudomonas aeruginosa. Weak binding was detected with other bacteria, including Vibrio parahaemolyticus, but no agglutination activity was observed. The biologically active PmFREP will not only be a crucial tool to elucidate the innate immune signaling in $P$. monodon and other economically important species, but will also aid in detection and prevention of shrimp bacterial infectious diseases.

The black tiger shrimp Penaeus monodon is an important economic animal of many countries, including Thailand ${ }^{1}$. However, there are many infectious diseases devastating shrimp farming. Viral pathogen such as white spot syndrome virus ${ }^{2}$, yellow head virus ${ }^{3}$, or shrimp baculovirus ${ }^{4}$ have costed severe economic loss and their molecular properties have been extensively investigated. There are various test kits available and factors in controlling infections are known ${ }^{5}$. Recently, bacterial pathogen such as Vibrio parahaemolyticus, causing the acute hepatopancreatic necrosis disease (AHPND), has emerged as a major disruption in the shrimp farming industry ${ }^{6}$. Very little is known about the interplay of the shrimp innate immune system and pathogenic bacteria. One key player is likely the lectins of the innate immune system ${ }^{7,8}$.

Lectins, or carbohydrate binding proteins, play important roles in pathogen recognition, especially in invertebrates where adaptive immunity is not as developed compared to vertebrates ${ }^{9}$. Lectins of the innate immune system generally can distinguish self from non-self by recognition of carbohydrate residues or specific glycan structure not present on the host cells. There are several families of animal lectins that are involved in the innate immunity, such as C-type lectins ${ }^{10}$, ficolins ${ }^{11}$, and intelectins ${ }^{12,13}$ (X-type lectin). Ficolins and intelectins are classified as fibrinogen-like lectins based on structural homology. In mammalian systems, ficolins are known to activate the lectin complement system for pathogen clearance ${ }^{7}$. Ficolins may act as an opsonin for phagocytosis as well ${ }^{14,15}$. However, the sequence of signaling events after bacteria recognition by lectins in invertebrate is largely unknown. Thus, we are interested in investigating the structure and function of fibrinogen-related lectin in shrimp, as it may have applications in bacterial disease prevention and treatment.

Fibrinogen-related lectins are widely distributed in the animal kingdom and they have diverse molecular structure (Fig. 1). Ficolins, found in both vertebrates and invertebrates, contain a cysteine-rich N-terminal region, a collagen-like region, and the carbohydrate recognition domain (CRD) at the C terminus (Fig. 1A). Because of the collagen-like region that is capable of forming a triple helix, ficolins can trimerize. The cysteine-rich region then mediates disulfide-linked oligomerization of the trimer into higher order oligomers, resulting in a fan- or

${ }^{1}$ Center of Excellence for Molecular Biology and Genomics of Shrimp, Department of Biochemistry, Faculty of Science, Chulalongkorn University, Bangkok, Thailand. ${ }^{2}$ Molecular Crop Research Unit, Department of Biochemistry, Faculty of Science, Chulalongkorn University, Bangkok, Thailand. ${ }^{3}$ Department of Biological Sciences, Faculty of Science, Centre for Biolmaging Sciences, National University of Singapore, Singapore, Singapore. ${ }^{\boxplus}$ email: kittikhun.w@chula.ac.th 
A) Ficolins

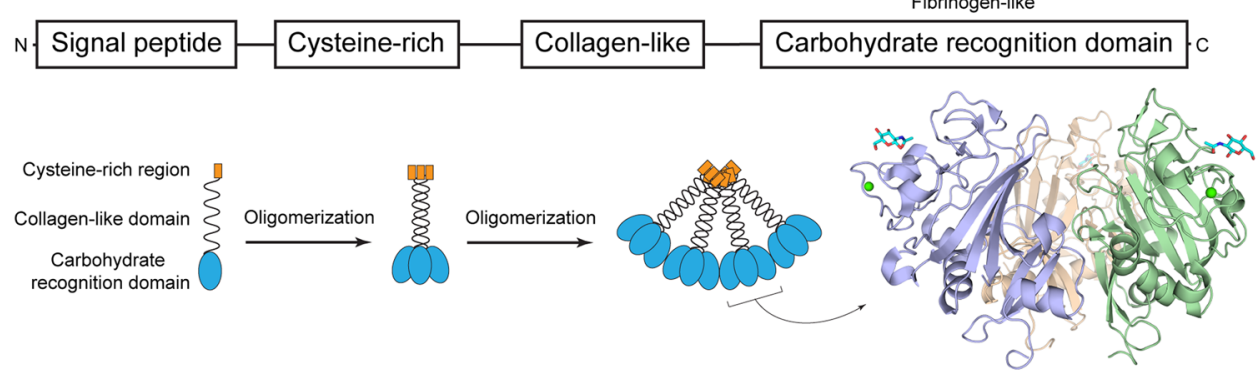

B) Tachylectin $5 \mathrm{~A}$
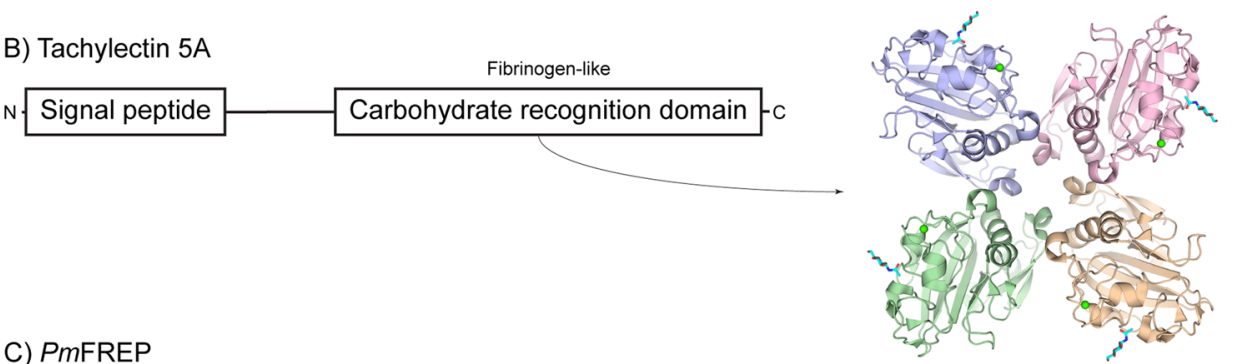

C) PmFREP

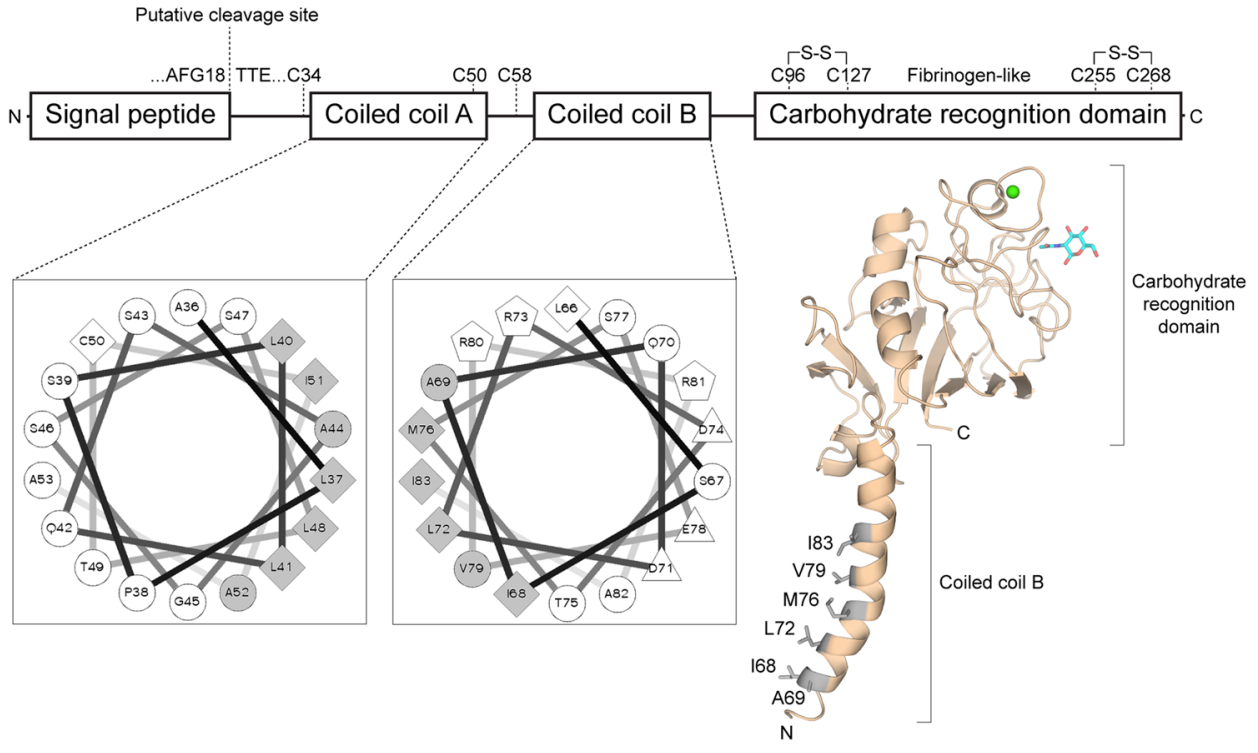

Figure 1. Comparison of fibrinogen-like lectin structures. (A) Ficolins. Each polypeptide chain can trimerize and oligomerize into a flower bouquet-like structure. The structure represents a trimeric CRD. (B) Tachylectin 5A. The structure represents the tetrameric CRD. and (C) PmFREP. The coiled coil regions are also represented with helical wheel diagrams showing the predicted amphipathic helices. The structure shown is a homology model of the CRD and coiled coil B built with human fibrinogen (PDB ID 2HPC) as the template.

flower bouquet-shaped molecular complex ${ }^{16,17}$. Ficolins binds $\mathrm{N}$-acetyl glucosamine (GlcNAc)-containing glycan and subsequent activate the innate immune system, such as the lectin complement pathway in mammals ${ }^{18,19}$. However, the signaling event in invertebrate is not well-studied. Another group of invertebrate fibrinogen-like lectin is tachylectin 5A (Fig. 1B). The protein has a simple primary structure of only the CRD. The protein is tetrameric and binds GlcNAc ${ }^{20,21}$. The protein is proposed to be involved in bacteria sensing and hemolymph clotting to seal the bacteria-exposed wound, but the molecular mechanism following ligand recognition remains unknown $^{22}$. Recently, a unique fibrinogen-like lectin from $P$. monodon was described. The protein has been cloned by various investigators, and named $P m \mathrm{FREP}^{23}$ or PL5-124. PmFREP binds bacterial peptidoglycan ${ }^{23}$, thus likely to bind GlcNAc as observed with ficolins and tachylectin 5A. PmFREP contains three cysteines outside of the CRD (Fig. 1C). Because of the odd number of cysteines, they are likely to participate in intermolecular disulfide bond formation. In contrast to ficolins, PmFREP does not contain the collagen-like sequence, but contains two coiled coil regions that likely for amphipathic helices and mediate higher order oligomerization. Thus, we predict that $P m$ FREP has a novel molecular assembly unique among fibrinogen-like lectins.

$P m$ FREP and related proteins have been purified from $P$. monodon hemolymph ${ }^{23,24}$. Because of the potential contamination of other GlcNAc-binding fibrinogen-related lectins, it is difficult to study the structure and 


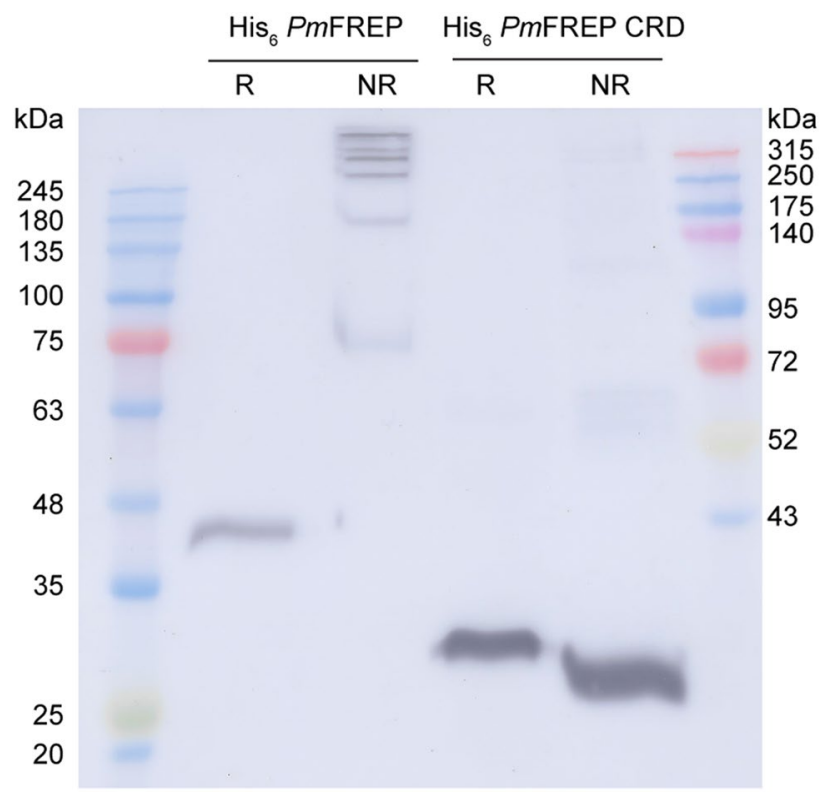

Figure 2. Western blot of $\mathrm{His}_{6}$ PmFREP and His6 PmFREP CRD under reducing (R) and non-reducing (NR) conditions. Anti-His ${ }_{6}$ antibody was used as the primary antibody.

function of PmFREP using the protein purified from the hemolymph. In addition, the complex architecture of $P m$ FREP may cause difficulties in recombinant protein expression. To date investigators that have cloned and studied PmFREP have reported recombinant expression of PmFREP-related proteins, such as PL5-2, in Escherichia coli, but not PmFREP (PL5-1) itself ${ }^{24}$. Given the potential intermolecular disulfide bonds and higher-order oligomerization, it is unlikely that $E$. coli and in vitro refolding of inclusion bodies can produce functional $P m$ FREP, or any PmFREP-related proteins. The problem of protein quality is a bottleneck in investigating lectin structure, function, and signaling in $P$. monodon. Therefore, we aim to produce functional recombinant $P m$ FREP to investigate its structure and function.

In this study, we produced recombinant PmFREP for biochemical and structural characterization. Due to the complex architectures of fibrinogen-related lectins, high level of protein expression was successful in insect cells. The dimer of pentamer structure of PmFREP was revealed by both biochemical methods and electron microscopy. Binding to $\mathrm{N}$-acetyl sugars and bacteria agglutination were also demonstrated. These results will not only be crucial for further investigation of immune signaling in shrimp, but will also help in combating bacterial infectious diseases in shrimp.

\section{Results}

PmFREP was cloned into various expression vectors for expression in bacteria (Escherichia coli), mammalian cells (HEK293T), and insect cells (Trichoplusia ni). In the E. coli system, no signal peptide was included in the coding sequences and both the $\mathrm{N}$ - and $\mathrm{C}$-terminal hexahistidine $\left(\mathrm{His}_{6}\right)$ tag was explored. Despite exploration of host strains and IPTG concentrations, no protein expression was detected both by SDS-PAGE and western blot against the $\mathrm{His}_{6}$ tag (data not shown). Thus, protein expression and secretion were further explored in mammalian and insect cells (Figure S1). Protein expression was barely observable for P $m$ FREP with its native signal peptide and a C-terminal $\mathrm{His}_{6}$ tag (Native SP PmFREP $\mathrm{His}_{6}$ ) when expressed and secreted from insect cells. Another expression construct examined is PmFREP with the Xenopus laevis embryonic epidermal lectin signal peptide and an $\mathrm{N}$-terminal His ${ }_{6}$ tag (XEEL SP His ${ }_{6}$ PmFREP, Figure S2A). This expression construct yielded higher amount of protein in the insect system compared to the mammalian system. Truncation of PmFREP to only the CRD with the XEEL signal peptide and a N-terminal $\mathrm{His}_{6} \operatorname{tag}\left(\mathrm{XEEL} \mathrm{SP} \mathrm{His}{ }_{6}\right.$ PmFREP, Figure S2B) when expressed in insect cells yielded high amount of protein in insect culture media, visible in SDS-PAGE with Coomassie Blue stain. Therefore, the insect expression system was used to express the constructs XEEL SP $\mathrm{His}_{6} \mathrm{PmFREP}_{\mathrm{F}} \mathrm{XEEL}$ SP $\mathrm{His}_{6}$ PmFREP CRD, yielding $\mathrm{His}_{6} P m$ FREP and $\mathrm{His}_{6}$ PmFREP CRD respectively. The protein was purified by Ni-NTA affinity chromatography for subsequent experiments (Figure S3). Correct cleavage of the signal peptide for both $\mathrm{His}_{6}$ PmFREP and $\mathrm{His}_{6}$ PmFREP CRD was verified with N-terminal protein sequencing (Figure S4).

With the ability to produce recombinant $P m$ FREP, we next explored the disulfide linked oligomeric states of PmFREP by examining the apparent molecular weight under reducing (with DTT in sample buffer) and nonreducing conditions (no DTT in sample buffer) (Fig. 2). $\mathrm{His}_{6}$ PmFREP ran as a single species under reducing conditions, but appear to assemble into large disulfide-linked oligomers of more than $315 \mathrm{kDa}$. On the other hand, $\mathrm{His}_{6} \mathrm{Pm} \mathrm{FREP} \mathrm{CRD}$ appeared monomeric both in reducing and non-reducing conditions, indicating that there are no intermolecular disulfide bonds in the CRD.

To further examine the quaternary structure of $P m$ FREP, both $\mathrm{His}_{6} P m$ FREP and $\mathrm{His}_{6} P m$ FREP CRD were examined by transmission electron microscopy (TEM) with negative staining (Fig. 3). $\mathrm{His}_{6}$ PmFREP appeared 
A) $\mathrm{His}_{6}$ PmFREP

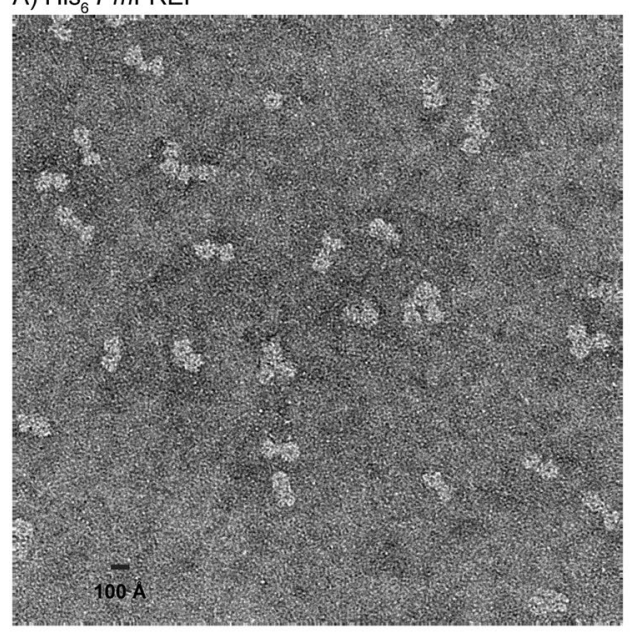

C) 2D class average of $\mathrm{His}_{6}$ PmFREP
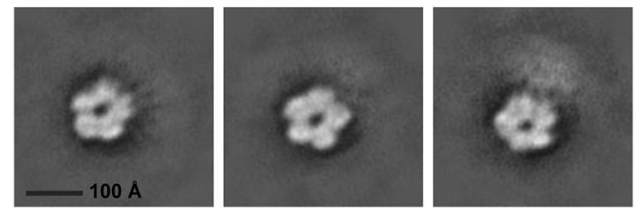

B) $\mathrm{His}_{6}$ PmFREP CRD
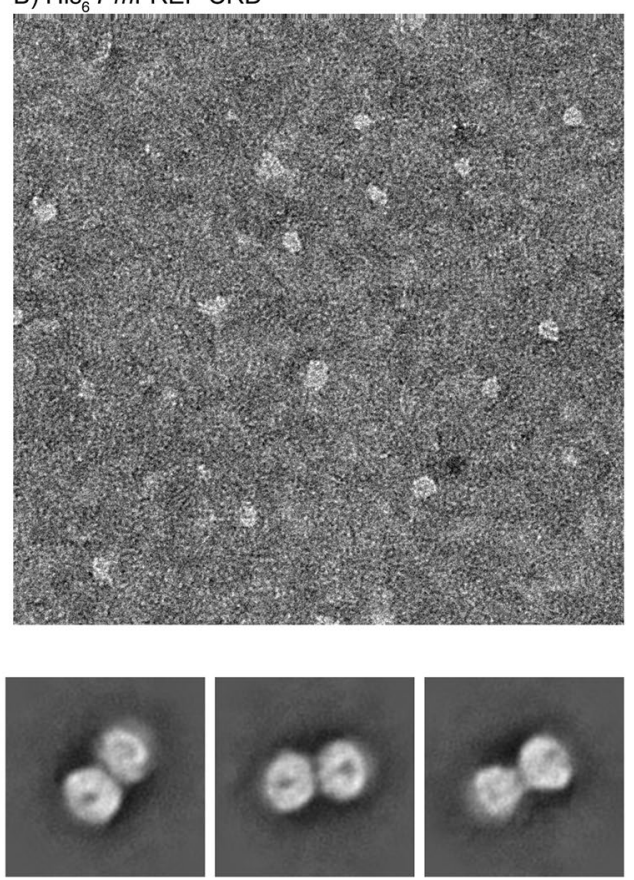

Figure 3. TEM micrograph of (A) $\mathrm{His}_{6}$ PmFREP, (B) His6 PmFREP CRD, and (C) $2 \mathrm{D}$ class averages of $\mathrm{His}_{6}$ PmFREP.

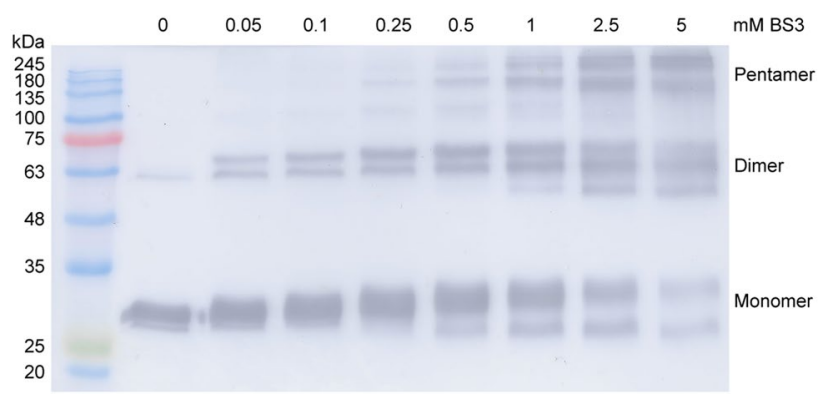

Figure 4. Crosslinking of PmFREP CRD with bis(sulfosuccinimidyl)suberate (BS3) at various concentrations. PmFREP was detected by western blot probed with an anti-His ${ }_{6}$ antibody.

as dumbbell-shaped molecules with the dimension of roughly $100 \times 200 \AA$. Two-dimensional class averaging suggested that the molecule is a dimer of pentamer with a flexible linker in between. This oligomeric structure is distinct from other fibrinogen-related lectins, such as mammalian ficolins, which are flower bouquet-shaped consisting of oligomers of trimers, or intelectins which are also trimer or oligomer of trimers. $\mathrm{His}_{6}$ PmFREP CRD appeared as $100 \AA$ particles, but we were not able to obtain consistent 2D class average. Dynamic light scattering (DLS) experiments also confirmed the sizes of $\mathrm{His}_{6}$ PmFREP $\left(215 \pm 36 \AA\right.$ ) and $\mathrm{His}_{6}$ P $m$ FREP CRD $(97 \pm 30 \AA)$ (Figure S5). These results suggested that $\mathrm{His}_{6}$ PmFREP CRD might still be able to oligomerize in solution, but the oligomeric conformation may not be as stable as the full length $\mathrm{His}_{6} \mathrm{P}_{m} \mathrm{FREP}$ protein. To examine whether $\mathrm{His}_{6}$ PmFREP CRD can oligomerize in solution, chemical cross-linking was performed (Fig. 4). As the concentration of the cross-linker was increased, species with the molecular weight consistent with dimers and pentamers were observed. These results suggested that $\mathrm{His}_{6}$ PmFREP CRD can self-associate in solution and were consistent with the TEM and DLS results.

To explore the ligand binding properties of PmFREP, we performed competitive elution assays (Fig. 5A). The proteins were bound to carbohydrate affinity resins and eluted with the corresponding monosaccharide or EDTA. $\mathrm{His}_{6}{ }_{2} m$ FREP can bind GlcNAc as expected for fibrinogen-like lectin. However, EDTA was not able to eluted $\mathrm{His}_{6}$ PmFREP from the GlcNAc resin. In contrast to the full length $\mathrm{His}_{6}{ }_{P} m \mathrm{FREP}, \mathrm{His}_{6}$ PmFREP CRD failed to bind any carbohydrate affinity resin. To further explore carbohydrate specificity of $\mathrm{His}_{6} \mathrm{P}_{m} \mathrm{FREP}, \mathrm{His}_{6} \mathrm{PmFREP}$ was bound to the GlcNAc resin and eluted with various carbohydrates (Fig. 5B). GlcNAc, N-acetylgalactosamine (GalNAc), $\mathrm{N}$-acetylmannosamine (ManNAc), and $\mathrm{N}$-acetylneuraminic acid (Neu5Ac) were able to elute $\mathrm{His}_{6}$ PmFREP from the GlcNAc resin. However, competitive elution was not observed with glycerol (Gro), ribose 


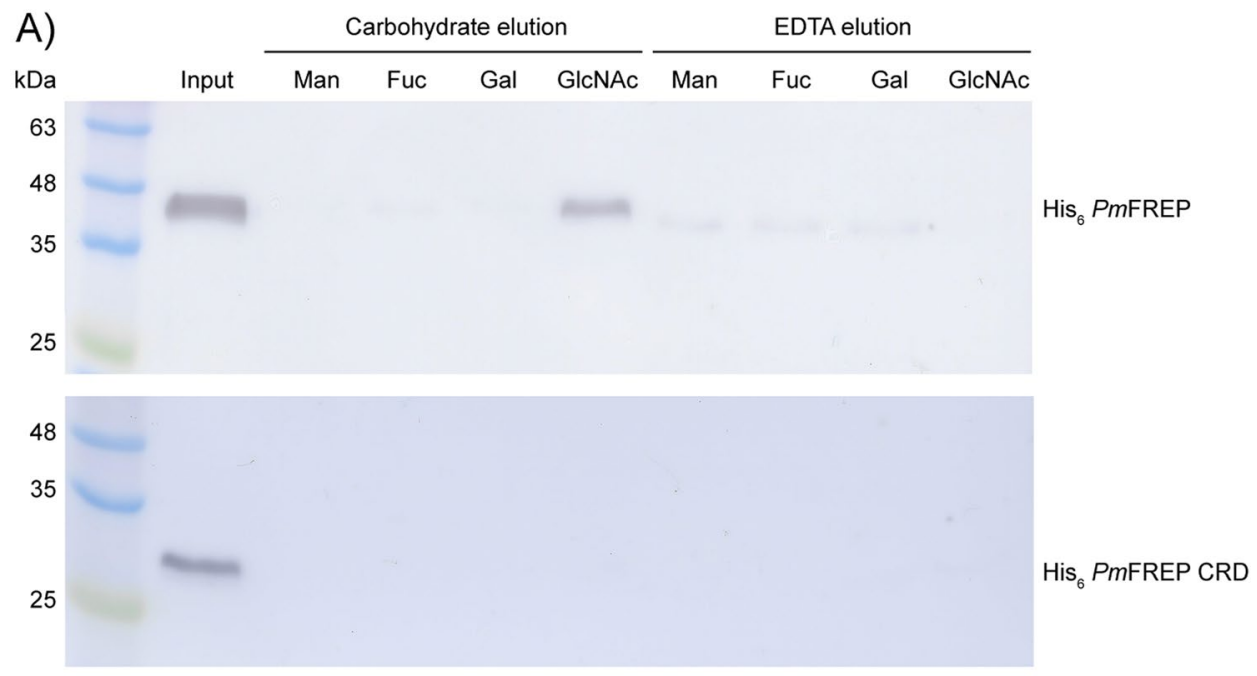

B)

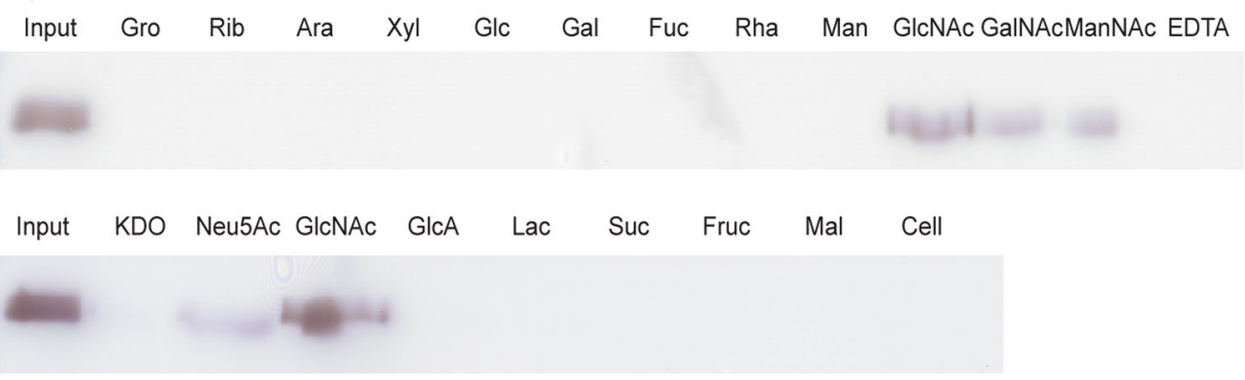

Figure 5. (A) Western blot analysis of $\mathrm{His}_{6}$ PmFREP (top panel) and $\mathrm{His}_{6}$ PmFREP CRD (bottom panel) bound to different carbohydrate resin and eluted with either the respective monosaccharide or EDTA. (B) Competitive elution of $\mathrm{His}_{6}$ PmFREP bound to GlcNAc resin by different soluble carbohydrates. Anti-His ${ }_{6}$ antibody was used as the primary antibody.

A) M-Ficolin

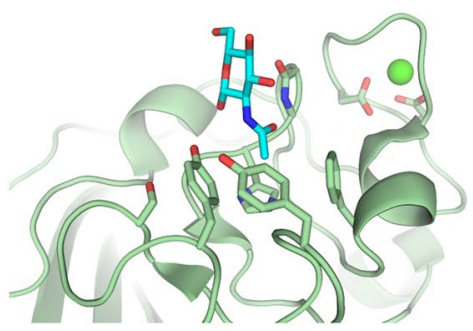

B) Tachylectin $5 \mathrm{~A}$

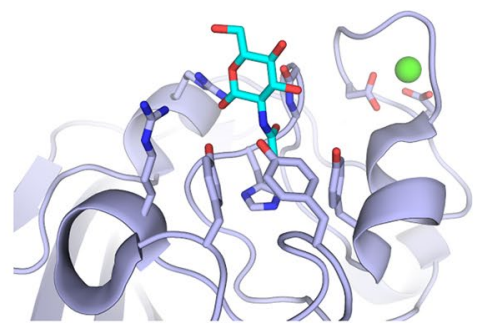

C) PmFREP (homology model)

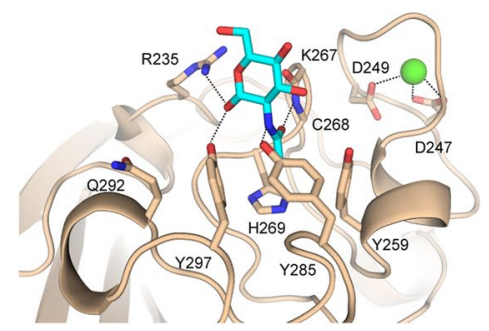

Figure 6. Comparison of the ligand binding site of (A) M-ficolin (crystal structure, PDB ID 2JHK), (B) Tachylectin 5A (crystal structure, PDB ID 1JC9), and (C) PmFREP (homology model using SWISS-MODEL ${ }^{44}$, PDB ID 1JC9 as the template). The GlcNAc ligand is shown in cyan and the structural calcium ion is shown in green.

(Rib), arabinose (Ara), xylose (Xyl), glucose (Glc), galactose (Gal), fucose (Fuc), rhamnose (Rha), mannose (Man), 3-deoxy-D-manno-2-octulosonic acid (KDO), glucoronic acid (GlcA), lactose (Lac), sucrose (Suc), fructose (Fruc), maltose (Mal), and cellobiose (Cell). These results suggested that $\mathrm{His}_{6} \mathrm{Pm}$ FREP was specific for acetyl group-containing carbohydrates, and while the ligand binding site and the calcium ion-binding residues were conserved (Fig. 6), the calcium ion is not required for ligand binding.

To investigate recognition of carbohydrates in cellular context, we examined agglutination of red blood cells by $\mathrm{His}_{6} P m$ FREP. Because of the dimer of pentamer arrangement, $\mathrm{His}_{6} \mathrm{PmFREP}$ is expected to agglutinate cells displaying its ligand. $\mathrm{His}_{6}$ PmFREP agglutinates red blood cells of A-, B- and O-type starting at concentration around $0.031 \mu \mathrm{M}$ (Fig. 7A). Agglutination was inhibited by GlcNAc, GalNAc, ManNAc, and Neu5Ac (Fig. 7B). However, glucose and EDTA could not inhibit agglutination. GlcNAc and GalNAc could inhibit agglutination 


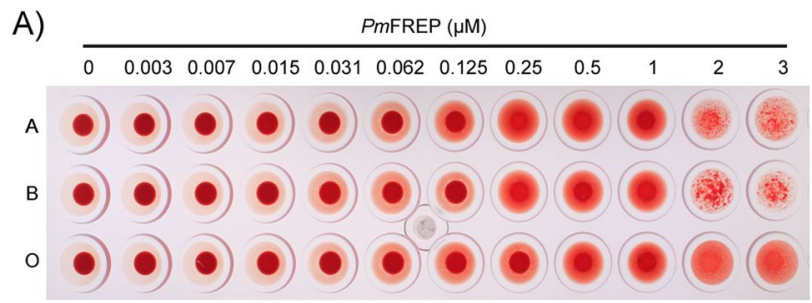

B)

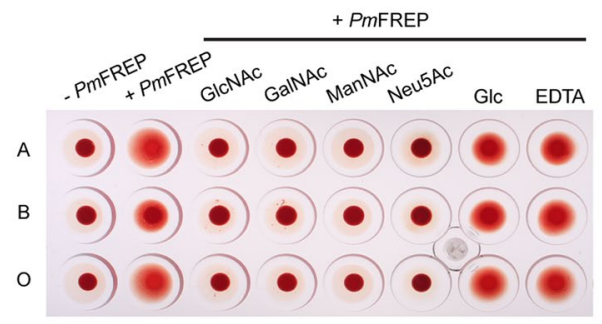

C)

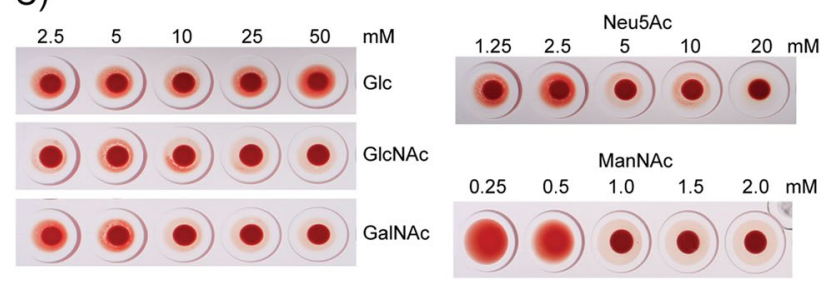

Figure 7. Agglutination of human red blood cells with $\mathrm{His}_{6}$ PmFREP. (A) Agglutination of different ABO blood type by $\mathrm{His}_{6}$ PmFREP at various concentrations. (B) Inhibition of ABO blood type agglutination by different carbohydrates (20 mM for Neu5Ac and $50 \mathrm{mM}$ for other carbohydrates) and EDTA. (C) Inhibition of A blood type agglutination by different carbohydrates at various concentrations.

at around $10 \mathrm{mM}$ (Fig. 7C). Inhibition of agglutination was observed at 5 and $1 \mathrm{mM}$ for Neu5Ac and ManNAc, respectively.

Because of its proposed role in P. monodon innate immune system, we next examined the ability of $\mathrm{His}_{6}$ $P m$ FREP to recognize bacteria (Fig. 8A). $\mathrm{His}_{6}$ PmFREP was bound to bacteria pellet and eluted with GlcNAc. The eluted protein solutions were then examined by western blot. His $_{6}$ PmFREP strongly recognized Pseudomonas aeruginosa. Noticeable binding was also observed with Bacillus subtilis, Staphylococcus aureus, Escherichia coli, and Vibrio parahaemolyticus. Very little to no binding was observed toward Micrococcus luteus and Salmonella enterica. Because the dimer of pentamer molecular architecture of PmFREP suggests that the protein can engage two bacteria simultaneously and cause agglutination, bacteria agglutination activity of PmFREP was explored (Fig. 8B). P. aeruginosa and V. parahaemolyticus were used in the agglutination because of the strong signal in the bacteria binding assay and the importance as a shrimp pathogen respectively. At the highest concentration of $\mathrm{His}_{6}$ PmFREP shown to agglutinate red blood cells $(3 \mu \mathrm{M})$, His ${ }_{6}$ PmFREP agglutinated $S$. aureus and this activity is inhibited by addition of GlcNAc. However, sequestration of $\mathrm{Ca}^{2+}$ ion by addition of EDTA did not inhibit agglutination. In contrast, $V$. parahaemolyticus was not agglutinated by $\mathrm{His}_{6} \mathrm{PmFREP}_{\text {. }}$

\section{Discussion}

Various investigators have purified PmFREP and its homologs from P. monodon hemolymph ${ }^{23-25}$. However, the degree of contamination by other homologs is unknown, which complicates further analysis of $P m$ FREP structure and function. Moreover, in contrast to other PmFREP homologs in shrimp, there is no report of expression or characterization of functional recombinant $P m \mathrm{FREP}^{23-25}$. We speculate that other investigators have encounter issues with bacterial production of P $m$ FREP. In our hands, we did not observe protein expression in $E$. coli whether the $\mathrm{His}_{6}$ tag was placed at the $\mathrm{N}$ - or $\mathrm{C}$-terminus. Thus, we conclude that bacterial expression system might not be suitable for PmFREP. Some protein expression is detected in mammalian cells, but scaling up protein production would be cost prohibitive, especially with transient transfection. Appreciable yield was observed when PmFREP was expressed in insect cells for both $\mathrm{His}_{6}$ PmFREP and $\mathrm{His}_{6}$ PmFREP CRD. Therefore, the insect cell expression is the system of choice for PmFREP. XEEL signal peptide was used because of the observation that XEEL, a fibrinogen-related lectin of the intelectin family, is highly expressed in insect cells ${ }^{12}$. Cleavage of the signal peptide occurred at the expected site as confirmed by $\mathrm{N}$-terminal protein sequencing. We reasoned that the placement of the $\mathrm{His}_{6}$ tag at the $\mathrm{N}$-terminus is more suitable because the C-terminal carboxyl group of other fibrinogen-related lectins, such as $\mathrm{H}$-ficolin ${ }^{26}$ or intelectins ${ }^{12,13}$, form a salt bridge with another amino acid residue. Placement of a C-terminal tag may disrupt this interaction and destabilize PmFREP. In this 
A)

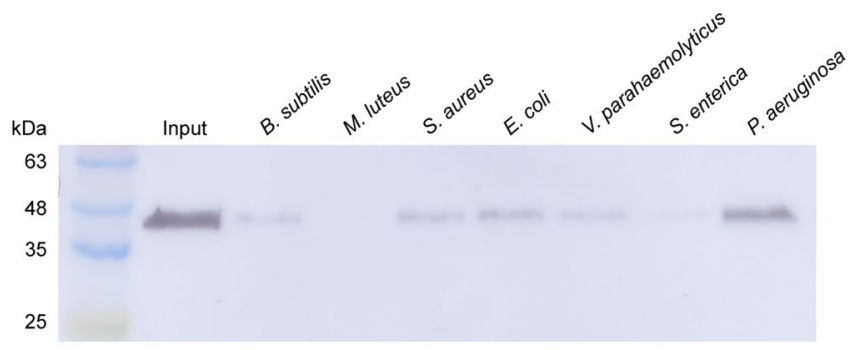

B)
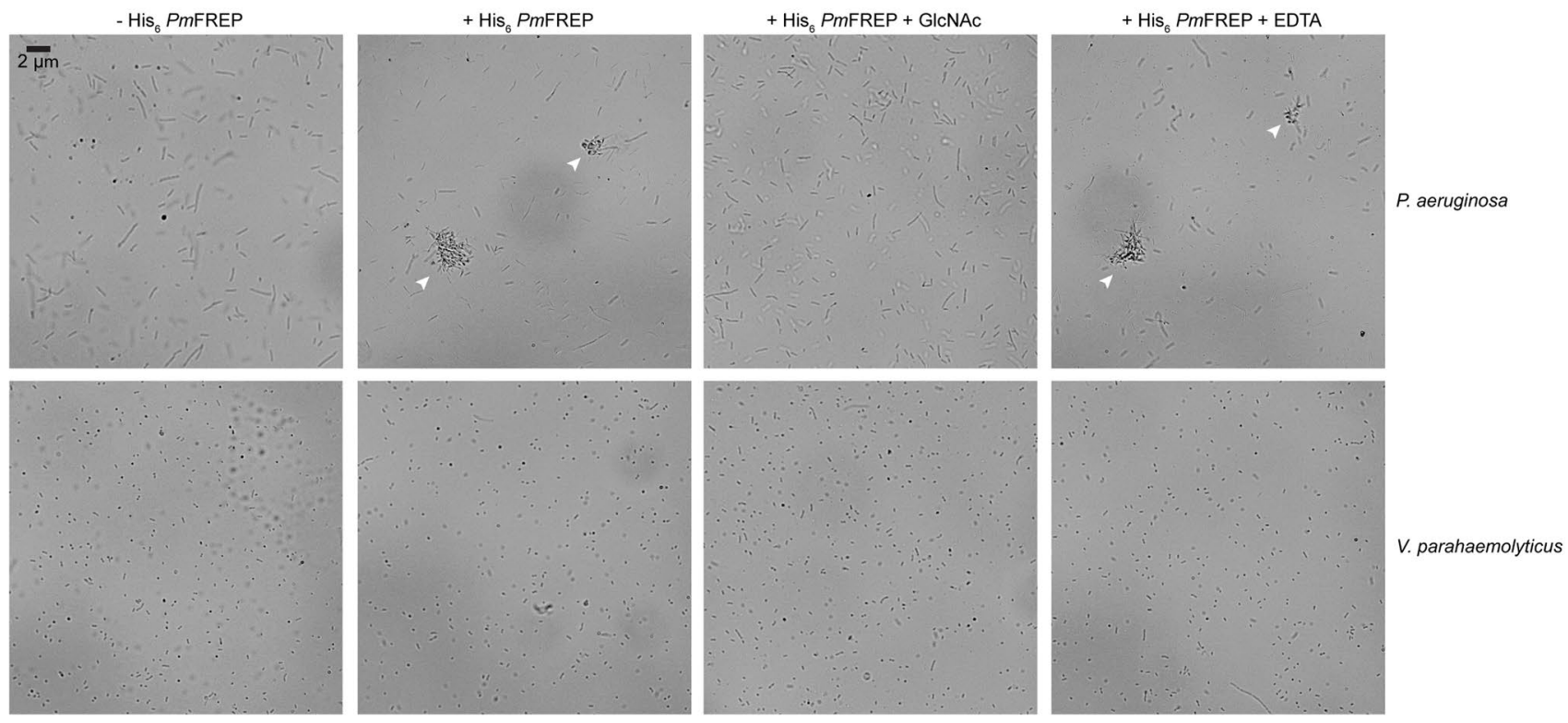

Figure 8. (A) Western blot of $\mathrm{His}_{6}$ PmFREP eluted from bacteria pellet with $100 \mathrm{mM}$ GlcNAc. Anti-His $\mathrm{P}_{6}$ antibody was used as the primary antibody. (B) Agglutination of bacteria with $\mathrm{His}_{6}$ PmFREP ( $\left.3 \mu \mathrm{M}\right)$. Clumps of bacteria are indicated with arrows.

case of human intelectin and XEEL, placement of the C-terminal tag drastically reduced the protein expression yield ${ }^{12,13}$. Utilization of the $\mathrm{His}_{6}$ tag is ubiquitous in biochemistry. The tag is placed at a protein terminus, which is not likely involved in interaction interfaces or any functional site ${ }^{27}$. Another advantage of the $\mathrm{His}_{6}$ tag is its function as an epitope tag. Thus, raising a specific antibody to PmFREP is not required. Moreover, having a tag separated from the protein sequence allow better control over future immunoprecipitation experiments because antibody binding to the tag will be less likely to interfere with interaction of PmFREP and other binding partners.

Because most lectins are oligomeric and the $\mathrm{N}$-terminus of $P m$ FREP contains an odd number of 3 cysteines (C34, C50, and C58), we reason that PmFREP might be able to form intermolecular disulfide bonds. SDS-PAGE analysis of $\mathrm{His}_{6} P m$ FREP and $\mathrm{His}_{6} P m$ FREP CRD under reducing and non-reducing conditions revealed that $\mathrm{His}_{6}$ $P m$ FREP is a disulfide-linked oligomer. The cysteines in the CRD are conserved among other fibrinogen-related lectins and are only involved in intramolecular disulfide bond formation ${ }^{21,26}$. This is consistent with the results that $\mathrm{His}_{6}$ PmFREP CRD is monomeric both in reducing and non-reducing conditions. Because of this intermolecular disulfide bonds, it is unlikely that recombinant PmFREP produced in E. coli, even if expressed, will be fully functional. Further examination of $\mathrm{His}_{6}$ P $m$ FREP quaternary structure by TEM revealed dumbbell-shaped molecules. Two-dimensional class averaging suggested that $\mathrm{His}_{6} \mathrm{PmFREP}$ is a dimer of pentamer with a flexible linker. The molecular weight of the dimer of pentamer, or decamer, would be around $345 \mathrm{kDa}$, which is consistent with the observation that $\mathrm{His}_{6}$ PmFREP ran at more than $315 \mathrm{kDa}$ in SDS-PAGE under non-reducing conditions.

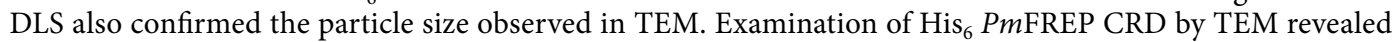
protein molecules about the size of the pentamer in the full length $\mathrm{His}_{6} \mathrm{PmFREP}_{\mathrm{F}}$ However, 2D class averaging did not yield sensible solutions, suggesting that $\mathrm{His}_{6}$ P $m$ FREP CRD might be able to oligomerize in solution,

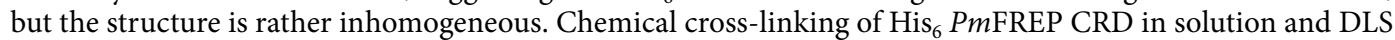

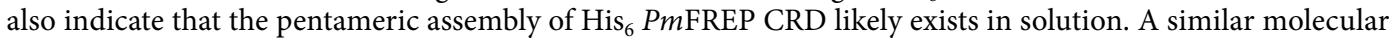
property is observed in XEEL, a fibrinogen-related lectin of the intelectin family ${ }^{12}$. XEEL is a dimer of trimer, and the CRD is capable of trimerization in solution even in the absence of the intermolecular disulfide bonds.

$\mathrm{His}_{6}$ PmFREP recognized GlcNAc, as expected from structural homology to other fibrinogen-related lectins (Fig. 5). Most residues in the binding sites that interact directly with GlcNAc (R235, NH of C268, H269, Y285, and Y297) are conserved between PmFREP and tachylectin $5 \mathrm{~A}^{21}$. The residues recognizing the $\mathrm{N}$-acetyl group 
(NH of C268, H269, Y285, and Y297) are conserved in human M-ficolin as well ${ }^{28}$. PmFREP could also bind GalNAc, ManNAc, and Neu5Ac. The red blood cell agglutination experiments suggested that PmFREP have the highest affinity towards ManNAc. However, the lack of experimental structural data, which we will continue to investigate, do not currently allow us to comments on specific interactions. It is also not clear whether ManNAc is a biologically relevant epitope since there is limited information on glycobiology of shrimp diseases. However, because PmFREP was first identified as a peptidoglycan-binding lectin ${ }^{23}$, the GlcNAc-binding activity might still be biologically relevant.

The calcium ion binding residues (D247 and D249) are conserved between PmFREP, tachylectin 5A, and M-ficolin, suggesting that PmFREP possesses $\mathrm{Ca}^{2+}$ ion binding activity. However, our results showed that $\mathrm{Ca}^{2+}$ ion was not required for GlcNAc binding. Because the $\mathrm{Ca}^{2+}$ ion is not directly participating in ligand binding, it is possible that the $\mathrm{Ca}^{2+}$ ion may only have structural and stability role for PmFREP. There are reports that other shrimp fibrinogen-related lectins require $\mathrm{Ca}^{2+}$ ion for ligand binding ${ }^{29-33}$. However, several ficolins are also capable of $\mathrm{Ca}^{2+}$-independent ligand binding ${ }^{19,34-36}$. The role of $\mathrm{Ca}^{2+}$ ion in PmFREP ligand binding modulated by protein stability need to be further investigated. In contrast to the full length $\mathrm{His}_{6} \mathrm{PmFREP}_{\mathrm{Fis}} \mathrm{P}_{6} \mathrm{PFREP}$ CRD did not bind the GlcNAc affinity resin. The reduction in ligand binding affinity could be due to the lack of intermolecular disulfide bonds that may stabilize the structure. This observation is consistent with the TEM results which indicates that $\mathrm{His}_{6}$ PmFREP CRD has relatively low structural homogeneity and may not be stable enough to bind GlcNAc with high affinity. In addition to potential reduction in structural stability, truncation of the full length protein to merely the CRD certainly reduced the multivalent binding capability of $\mathrm{His}_{6} P m$ FREP. Multivalent binding event is well documented and is utilized ubiquitously in nature to increase apparent binding affinity, or avidity, especially in immune proteins and signaling events ${ }^{37-39}$. Therefore, reduction in binding avidity is expected for any lectin when the oligomeric state is reduced.

$\mathrm{His}_{6}$ PmFREP clearly recognized P. aeruginosa. Binding is less strong towards B. subtilis, S. aureus, E. coli, and $V$. parahaemolyticus. Because $\mathrm{His}_{6} P m$ FREP is a dimer of pentamer, the molecule should be able to engage two bacteria simultaneously and cause agglutination. Indeed, His ${ }_{6}$ PmFREP agglutinated P. aeruginosa and this activity is inhibited by the presence of GlcNAc. Addition of EDTA to sequester $\mathrm{Ca}^{2+}$ ion did not inhibit agglutination. These results are consistent with the ligand binding and red blood cell agglutination experiments

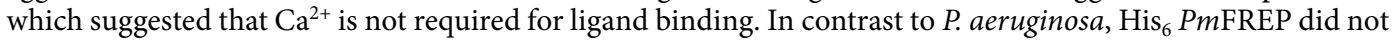

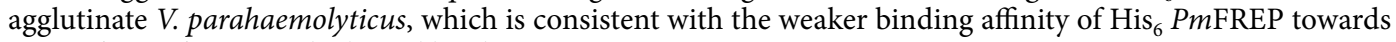
V. parahaemolyticus in the ligand binding assay.

In conclusion, we have characterized the recombinant fibrinogen-like lectin PmFREP from P. monodon expressed in insect cells. The protein is a dimer of pentamer with intermolecular disulfide bonds at the N-terminus. This dimer of pentamer molecular architecture is novel among fibrinogen-related lectins. PmFREP binds GlcNAc like other fibrinogen-related lectins, such as tachylectin 5A and ficolins. In addition, binding to GalNAc, ManNAc, and Neu5Ac was observed. $\mathrm{Ca}^{2+}$ is not required for ligand binding, but may have structural roles as the calcium binding residues are conserved. The CRD itself is capable of oligomerization in solution, but cannot bind the GlcNAc ligand. PmFREP recognizes and agglutinates P. aeruginosa in a $\mathrm{Ca}^{2+}$-independent manner, but cannot agglutinate the shrimp pathogen $V$. parahaemolyticus although weak binding is observed in the bacteria binding assay. The information obtained and $\mathrm{His}_{6}$ PmFREP produced in the study will be useful for further biochemical investigation and the signaling pathway of innate immune lectins in shrimp that may help prevent and treat bacterial infectious disease in shrimp in the future.

\section{Methods}

Expression plasmids and protein expression. For expression in insect cells, the open reading frame for PmFREP (GenBank accession number AIE45535) was amplified from $P$. monodon hemocyte cDNA by the primers 5'-GCGCGGATCCATGGCGCTCTTGCACAAGTTCATG-3' and 5'-ATGCGGTACCTCATTAGAA TGCCGGCCTTATCATCATTGTTG-3', and cloned into the BamHI and KpnI sites of pFastBacl (pFastBac1 PmFREP). After sequencing, G184D substitution was noted in all the 3 clones sequenced and was thus assumed to be a natural variation. The plasmid for expression of PmFREP His6 was made similarly, but with $5^{\prime}$-ATGC GGTACCTCATTAATGGTGATGGTGGTGATGGAATGCCGGCCTTATCATCATTGTTG-3' as the reverse primer (pFastBacl PmFREP $\mathrm{His}_{6}$ ). To create the expression construct for $\mathrm{His}_{6}$ PmFREP with Xenopus laevis embryonic epidermal lectin signal peptide (XEEL SP), pFastBacl PmFREP was used as a template to amplify with the primer $5^{\prime}$-CCAGCAGGGCACGCTGGTTCACATCACCACCATCACCACAGCGGTACAACAGAA CGAACAGATACCGCGG-3' and the same reverse primer used to make pFastBac1 PmFREP. The PCR product was amplified again with the primers 5'-ATGCGGTACCATGTTGTCATATAGCCTGTTGCTTTTTGCA CTTGCATTTCCAGCAGGGCACGCTGGTTCA- ${ }^{\prime}$ and the same reverse primer. The PCR product was then cloned into the BamHI and KpnI sites of pFastBac1 (pFastBac1 XEEL SP His ${ }_{6}$ PmFREP). To create the expression construct for the carbohydrate recognition domain of PmFREP with the XEEL signal peptide (XEEL SP $\mathrm{His}_{6}$ PmFREP CRD), pFastBacl PmFREP was used as a template to amplify with the primer 5'- CCAGCAGGG CACGCTGGTTCACATCACCACCATCACCACGGTTCACGGCCGAGGCACTGCCGCGACCTGC-3' and the same reverse primer used to make pFastBacl PmFREP. The PCR product was re-amplified and cloned into pFastBacl in the same manner as pFastBac1 XEEL SP His ${ }_{6}$ PmFREP (pFastBac1 XEEL SP His ${ }_{6}$ PmFREP CRD). Insect cell transfection, baculovirus production in Sf21, and protein production in Trichoplusia ni were carried out as described previously ${ }^{12}$.

The bacterial expression vectors were constructed using pFastBacl PmFREP His ${ }_{6}$ as a template for PCR. For the expression plasmid of $P m$ FREP His $_{6}$, the open reading frame was amplified using the primers $5^{\prime}$-TGGCCA TGGGGACAACAGAACGAACAGATACC-3' and 5'-TATACTCGAGGAATGCCGGCCTTATCATCATTG-3', and then cloned into the NcoI and XhoI sites of pET28a (pET28a PmFREP His ${ }_{6}$ ). For the expression plasmid 
of $\mathrm{His}_{6}$ PmFREP, the open reading frame was amplified using the primers $5^{\prime}$-ATACCATGGGCCATCATCATC ATCATCACGGGACAACAGAACGAACAGATACCG-3' and 5' - CTCGGATCCTCATTAGAATGCCGGCCT TATCATC - $3^{\prime}$, and then cloned into the NcoI and BamHI sites of pET28a (pET28a His ${ }_{6}$ PmFREP). For protein expression in Escherichia coli, the plasmids were each transformed into Tuner(DE3) and Rosetta(DE3). After growing at $37^{\circ} \mathrm{C}$ until OD600 reached 0.6, protein expression was induced by $0,0.5$, and $1 \mathrm{mM}$ IPTG for $6 \mathrm{~h}$. Cells were collected by centrifugation and lysed by sonication. The soluble and insoluble fractions were analyzed by SDS-PAGE and western blot.

The mammalian expression plasmid for $\mathrm{His}_{6}$ PmFREP with the XEEL signal peptide was constructed by PCR amplification of the XEEL SP His ${ }_{6}$ PmFREP open reading frame from pFastBac1 XEEL SP His ${ }_{6}$ PmFREP using the primers 5'-ATGCGGTACCATGTTGTCATATAGCCTGTTGCTTTTTGCACTTGCATTTCCAGCAGGG CACGCTGGTTCA-3' and 5'-CTCGGATCCTCATTAATGGTGATGGTGGTGATGG-3' ${ }^{\prime}$, and then cloned into the KpnI and BamHI sites of pcDNA4 myc His A (pcDNA4 myc His A XEEL SP His ${ }_{6}$ PmFREP). For protein expression in mammalian cells, HEK293T was cultured in Dulbecco's Modified Eagle Medium (DMEM) supplemented with $10 \%$ fetal bovine serum and $100 \mathrm{U} / \mathrm{mL}$ of penicillin-streptomycin (Gibco). Prior to transfection, cells were plated at $10^{6}$ cells/well in a 6-well plate and incubated overnight. The transfection mixture contains $2 \mu \mathrm{g}$ plasmid and $6 \mu \mathrm{g}$ PEI (linear MW 25,000, Polysciences) in $200 \mu \mathrm{L}$ of Opti-MEM (Gibco). After 30 min incubation, Opti-MEM was added to the total volume of $1 \mathrm{~mL}$. The culture media was aspirated from the adherent cells and replaced with the transfection mixture. After $4 \mathrm{~h}$, SFM4HKE293 (1.5 mL, HyClone) was added. Protein secretion was allowed to proceed for $48 \mathrm{~h}$ before the culture media was collected for analysis by western blot.

Purification of $\mathrm{His}_{6}$ PmFREP and $\mathrm{His}_{6}$ PmFREP CRD. Insect culture media containing secreted protein were dialyzed against $20 \mathrm{mM}$ Bis-Tris pH 6.5 and $150 \mathrm{mM} \mathrm{NaCl}$ to reduce media component precipitation and subsequently dialyzed against $20 \mathrm{mM}$ HEPES pH 7.5, $150 \mathrm{mM} \mathrm{NaCl}$, and $25 \mathrm{mM}$ imidazole (loading buffer). The dialyzed insect culture media was then applied a Ni-NTA column equilibrated with the loading buffer. The column was washed with the loading buffer and the protein eluted with $20 \mathrm{mM}$ HEPES pH 7.5, $150 \mathrm{mM} \mathrm{NaCl}$, and $250 \mathrm{mM}$ imidazole. Buffer was exchanged to $20 \mathrm{mM}$ HEPES pH 7.5, $150 \mathrm{mM} \mathrm{NaCl}$, and $10 \mathrm{mM} \mathrm{CaCl}_{2}$

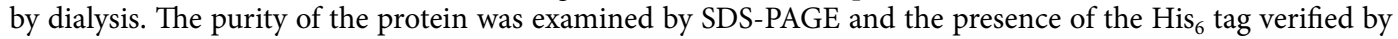
western blot. Protein concentrations were determined using spectrophotometry at $280 \mathrm{~nm}$. For $\mathrm{His}_{6} P m$ FREP $(34.5 \mathrm{kDa})$ the extinction coefficient is $63,745 \mathrm{M}^{-1} \mathrm{~cm}^{-1}$ or 1 absorbance unit $=1.849 \mathrm{mg} / \mathrm{mL}$. For His ${ }_{6} P m$ FREP CRD $(26.6 \mathrm{kDa})$ the extinction coefficient is $63,620 \mathrm{M}^{-1} \mathrm{~cm}^{-1}$ or 1 absorbance unit $=2.396 \mathrm{mg} / \mathrm{mL}$. N-terminal sequencing of the purified proteins was performed with ABI 494 Protein Sequencer (Tufts University Core Facility, Tufts Medical School). Dynamic light scattering data were collected on Malvern Zetasizer Nano ZS using microcuvettes $(40 \mu \mathrm{L})$.

Negative stain and transmission electron microscopy. Samples were diluted in $5 \mathrm{mM}$ HEPES pH $7.5,1 \mathrm{mM} \mathrm{CaCl}_{2}$ to concentration of $5 \mu \mathrm{g} / \mathrm{mL}$. Negative stain was carried out as previously described ${ }^{40}$. TEM data acquisition was performed on FEI Tecnai T12 electron microscope operating at $120 \mathrm{kV}$ equipped with $4 \mathrm{kx} 4 \mathrm{k}$ CCD camera (Gatan Ultrascan). Images were taken at magnifications of 110,000 ( $0.7 \AA /$ pixel, defocus $-0.5 \mu \mathrm{m})$. Images format conversion was performed with EMAN2 ${ }^{41}$. Image processing and $2 \mathrm{D}$ class averaging were performed with cisTEM ${ }^{42}$.

His $_{6}$ PmFREP CRD crosslinking. Bis(sulfosuccinimidyl)suberate (BS3, Pierce) was dissolved in water and added to $90 \mu \mathrm{L}$ solutions of $\mathrm{His}_{6}$ PmFREP CRD $(80 \mu \mathrm{g} / \mathrm{mL}$ in $20 \mathrm{mM}$ HEPES pH 7.5, $150 \mathrm{mM} \mathrm{NaCl}$, and $10 \mathrm{mM}$ $\mathrm{CaCl}_{2}$ ) to achieve the final concentrations of $0,0.05,0.1,0.25,0.5,1,2.5$, and $5 \mathrm{mM}$ with the total volume of $100 \mu \mathrm{L}$. The reaction mixture was incubated at room temperature for $30 \mathrm{~min}$ and the quenched by addition of $1 \mathrm{M}$ Tris $\mathrm{pH} 7.5$ to the final concentration of $20 \mathrm{mM}$. The product was then analyzed by western blot.

Carbohydrate binding assay. Affinity resins containing different carbohydrate ligands were prepared as previously described ${ }^{43}$. Purified $\mathrm{His}_{6}$ PmFREP or His $_{6}$ PmFREP CRD in $20 \mathrm{mM}$ HEPES pH 7.5, $150 \mathrm{mM} \mathrm{NaCl}$, and $10 \mathrm{mM} \mathrm{CaCl}_{2}$ (binding buffer). The protein solution $(20 \mu \mathrm{g} / \mathrm{mL}, 100 \mu \mathrm{L})$ was then applied to $100 \mu \mathrm{L}$ of affinity resin in Bio-Rad Micro Bio-Spin column that had previously been washed with water and pre-equilibrated with the binding buffer. After centrifugation, the resin was washed with $3 \times 250 \mu \mathrm{L}$ of the binding buffer. The bound protein was then eluted with $2 \times 100 \mu \mathrm{L}$ of the elution buffer and analyzed by western blot with anti-His ${ }_{6}$ antibody as the primary antibody. For competitive elution with monosaccharide, the elution buffer is $20 \mathrm{mM}$ HEPES pH 7.5, $150 \mathrm{mM} \mathrm{NaCl}, 10 \mathrm{mM} \mathrm{CaCl}_{2}$, and $100 \mathrm{mM}$ monosaccharide. For EDTA elution, the elution buffer is $20 \mathrm{mM}$ HEPES $\mathrm{pH} 7.5,150 \mathrm{mM} \mathrm{NaCl}$, and $10 \mathrm{mM}$ EDTA. The eluted samples were precipitated in cold acetone ( 4 volume) at $-20^{\circ} \mathrm{C}$ for $2 \mathrm{~h}$. The solution was centrifuged at $14,000 \times g$ at $4{ }^{\circ} \mathrm{C}$ for $30 \mathrm{~min}$. The supernatant was removed and the pellet dried at room temperature. The precipitate was dissolves in SDS-PAGE sample buffer and subjected to Western blot using anti-His ${ }_{6}$ antibody.

Red blood cell agglutination assay. Human red blood cells were purchased from Thai Red Cross and washed with the binding buffer before use. $\mathrm{His}_{6}$ PmFREP was incubated with a suspension of $3 \%(\mathrm{v} / \mathrm{v})$ human red blood cells $(\mathrm{A}, \mathrm{B}$, and $\mathrm{O})$ in 72 -well Terasaki plates. In the inhibition experiments, various sugars were incubated with $0.5 \mu \mathrm{M} \mathrm{His}_{6}$ PmFREP and 3\% (v/v) human red blood cells was then added, agglutination activity was observed as diffused cells that do not settle to the bottom of the well compared to untreated cells. 
Bacteria binding and agglutination assay. All bacteria were cultured in nutrient broth, except V. parahaemolyticus that was cultured in nutrient broth with $3 \% \mathrm{NaCl}$. Bacteria $(50 \mathrm{mg})$ were pelleted and washed with $250 \mu \mathrm{L}$ of the binding buffer. The pellets were then suspended in $\mathrm{His}_{6}$ PmFREP $(20 \mu \mathrm{g} / \mathrm{mL}, 250 \mu \mathrm{L})$ then incubated on ice for $10 \mathrm{~min}$. The pellets were washed with $3 \times 250 \mu \mathrm{L}$ of the binding buffer. The protein was then eluted from each pellet by $100 \mu \mathrm{L}$ of $20 \mathrm{mM}$ HEPES pH 7.5, $150 \mathrm{mM} \mathrm{NaCl}, 10 \mathrm{mM} \mathrm{CaCl}$, and $100 \mathrm{mM}$ monosaccharide. The eluted protein was analyzed by western blot with anti-His ${ }_{6}$ antibody as the primary antibody.

For the agglutination assay, the bacteria were grown, washed, and resuspended in the binding buffer as mentioned above. The bacteria solution $(50 \mu \mathrm{L})$ was mixed with $\mathrm{His}_{6}$ PmFREP $(100 \mu \mathrm{g} / \mathrm{mL}$ or $3 \mu \mathrm{M}, 10 \mu \mathrm{L})$. The total volume was then adjusted to $70 \mu \mathrm{L}$ with the binding buffer with or without the addition of GlcNAc or EDTA to the final concentration of 10 or $25 \mathrm{mM}$, respectively. A $20 \mu \mathrm{L}$ sample of each mixture was then photographed under an Olympus CX31 light microscope equipped with a Canon EOS 650D digital camera.

Received: 9 August 2020; Accepted: 19 January 2021

Published online: 03 February 2021

\section{References}

1. Sampantamit, T. et al. Aquaculture production and its environmental sustainability in Thailand: Challenges and potential solutions. Sustainability 12, 2010 (2020).

2. Sanchez-Paz, A. White spot syndrome virus: An overview on an emergent concern. Vet. Res. 41, 43. https://doi.org/10.1051/vetre s/2010015 (2010).

3. Munro, J. \& Owens, L. Yellow head-like viruses affecting the penaeid aquaculture industry: A review. Aquac. Res. 38, 893-908. https://doi.org/10.1111/j.1365-2109.2007.01735.x (2007).

4. Rajendran, K. V., Makesh, M. \& Karunasagar, I. Monodon baculovirus of shrimp. Indian J. Virol. 23, 149-160. https://doi. org/10.1007/s13337-012-0086-z (2012).

5. Chaivisuthangkura, P., Longyant, S. \& Sithigorngul, P. Immunological-based assays for specific detection of shrimp viruses. World J. Virol. 3, 1-10. https://doi.org/10.5501/wjv.v3.i1.1 (2014).

6. Tang, K. F. J. \& Bondad-Reantaso, M. G. Impacts of acute hepatopancreatic necrosis disease on commercial shrimp aquaculture. Revue scientifique et technique (International Office of Epizootics) 38, 477-490. https://doi.org/10.20506/rst.38.2.2999 (2019).

7. Fujita, T., Matsushita, M. \& Endo, Y. The lectin-complement pathway-its role in innate immunity and evolution. Immunol. Rev. 198, 185-202 (2004).

8. Suresh, R. \& Mosser, D. M. Pattern recognition receptors in innate immunity, host defense, and immunopathology. Adv. Physiol. Educ. 37, 284-291. https://doi.org/10.1152/advan.00058.2013 (2013).

9. Loker, E. S., Adema, C. M., Zhang, S. M. \& Kepler, T. B. Invertebrate immune systems-not homogeneous, not simple, not well understood. Immunol. Rev. 198, 10-24 (2004).

10. Brown, G. D., Willment, J. A. \& Whitehead, L. C-type lectins in immunity and homeostasis. Nat. Rev. Immunol. 18, 374-389. https ://doi.org/10.1038/s41577-018-0004-8 (2018).

11. Endo, Y., Matsushita, M. \& Fujita, T. The role of ficolins in the lectin pathway of innate immunity. Int. J. Biochem. Cell Biol. 43, 705-712. https://doi.org/10.1016/j.biocel.2011.02.003 (2011).

12. Wangkanont, K., Wesener, D. A., Vidani, J. A., Kiessling, L. L. \& Forest, K. T. Structures of xenopus embryonic epidermal lectin reveal a conserved mechanism of microbial glycan recognition. J. Biol. Chem. 291, 5596-5610. https://doi.org/10.1074/jbc. M115.709212 (2016)

13. Wesener, D. A. et al. Recognition of microbial glycans by human intelectin-1. Nat. Struct. Mol. Biol. 22, 603-610 (2015).

14. Bidula, S., Sexton, D. W. \& Schelenz, S. Serum opsonin ficolin-A enhances host-fungal interactions and modulates cytokine expression from human monocyte-derived macrophages and neutrophils following Aspergillus fumigatus challenge. Med. Microbiol. Immunol. 205, 133-142. https://doi.org/10.1007/s00430-015-0435-9 (2016).

15. Endo, Y., Matsushita, M. \& Fujita, T. New insights into the role of ficolins in the lectin pathway of innate immunity. Int. Rev. Cell Mol. Biol. 316, 49-110. https://doi.org/10.1016/bs.ircmb.2015.01.003 (2015).

16. Ohashi, T. \& Erickson, H. P. The disulfide bonding pattern in ficolin multimers. J. Biol. Chem. 279, 6534-6539. https://doi. org/10.1074/jbc.M310555200 (2004).

17. Lacroix, M. et al. Residue Lys57 in the collagen-like region of human L-ficolin and its counterpart Lys47 in $\mathrm{H}$-ficolin play a key role in the interaction with the mannan-binding lectin-associated serine proteases and the collectin receptor calreticulin. J. Immunol. 182, 456-465. https://doi.org/10.4049/jimmunol.182.1.456 (2009).

18. Matsushita, M. et al. A novel human serum lectin with collagen- and fibrinogen-like domains that functions as an opsonin. J. Biol. Chem. 271, 2448-2454. https://doi.org/10.1074/jbc.271.5.2448 (1996).

19. Ohashi, T. \& Erickson, H. P. Two oligomeric forms of plasma ficolin have differential lectin activity. J. Biol. Chem. 272, 14220-14226. https://doi.org/10.1074/jbc.272.22.14220 (1997).

20. Gokudan, S. et al. Horseshoe crab acetyl group-recognizing lectins involved in innate immunity are structurally related to fibrinogen. Proc. Natl. Acad. Sci. U.S.A. 96, 10086-10091 (1999).

21. Kairies, N. et al. The 2.0-A crystal structure of tachylectin 5A provides evidence for the common origin of the innate immunity and the blood coagulation systems. Proc. Natl. Acad. Sci. U.S.A. 98, 13519-13524. https://doi.org/10.1073/pnas.201523798 (2001).

22. Kawabata, S. \& Tsuda, R. Molecular basis of non-self recognition by the horseshoe crab tachylectins. Biochem. Biophys. Acta. 1572, 414-421. https://doi.org/10.1016/s0304-4165(02)00322-7 (2002).

23. Udompetcharaporn, A. et al. Identification and characterization of a QM protein as a possible peptidoglycan recognition protein (PGRP) from the giant tiger shrimp Penaeus monodon. Dev. Comp. Immunol. 46, 146-154. https://doi.org/10.1016/j. dci.2014.04.003 (2014).

24. Angthong, P., Roytrakul, S., Jarayabhand, P. \& Jiravanichpaisal, P. Characterization and function of a tachylectin 5-like immune molecule in Penaeus monodon. Dev. Comp. Immunol. 76, 120-131. https://doi.org/10.1016/j.dci.2017.05.023 (2017).

25. Angthong, P., Roytrakul, S., Jarayabhand, P. \& Jiravanichpaisal, P. Involvement of a tachylectin-like gene and its protein in pathogenesis of acute hepatopancreatic necrosis disease (AHPND) in the shrimp, Penaeus monodon. Dev. Comp. Immunol. 76, $229-237$. https://doi.org/10.1016/j.dci.2017.06.011 (2017).

26. Garlatti, V. et al. Structural insights into the innate immune recognition specificities of L- and H-ficolins. EMBO J. 26, 623-633. https://doi.org/10.1038/sj.emboj.7601500 (2007).

27. Carson, M., Johnson, D. H., McDonald, H., Brouillette, C. \& Delucas, L. J. His-tag impact on structure. Acta Crystallogr. Sect. D Biol. Crystallogr. 63, 295-301. https://doi.org/10.1107/s0907444906052024 (2007).

28. Garlatti, V. et al. Structural basis for innate immune sensing by M-ficolin and its control by a pH-dependent conformational switch. J. Biol. Chem. 282, 35814-35820. https://doi.org/10.1074/jbc.M705741200 (2007). 
29. Senghoi, W., Thongsoi, R., Yu, X. Q., Runsaeng, P. \& Utarabhand, P. A unique lectin composing of fibrinogen-like domain from Fenneropenaeus merguiensis contributed in shrimp immune defense and firstly found to mediate encapsulation. Fish Shellfish Immunol. 92, 276-287. https://doi.org/10.1016/j.fsi.2019.06.009 (2019).

30. Zhang, X. W. et al. Cloning and characterization of two different ficolins from the giant freshwater prawn Macrobrachium rosenbergii. Dev. Comp. Immunol. 44, 359-369. https://doi.org/10.1016/j.dci.2014.01.009 (2014).

31. Chai, Y. M., Zhu, Q., Yu, S. S., Zhao, X. F. \& Wang, J. X. A novel protein with a fibrinogen-like domain involved in the innate immune response of Marsupenaeus japonicus. Fish Shellfish Immunol. 32, 307-315. https://doi.org/10.1016/j.fsi.2011.11.020 (2012).

32. Sun, J. J. et al. A fibrinogen-related protein (FREP) is involved in the antibacterial immunity of Marsupenaeus japonicus. Fish Shellfish Immunol. 39, 296-304. https://doi.org/10.1016/j.fsi.2014.05.005 (2014).

33. Han, K. et al. Novel fibrinogen-related protein with single FReD contributes to the innate immunity of Macrobrachium rosenbergii. Fish Shellfish Immunol. 82, 350-360. https://doi.org/10.1016/j.fsi.2018.08.036 (2018).

34. Sugimoto, R. et al. Cloning and characterization of the Hakata antigen, a member of the ficolin/opsonin p35 lectin family. J. Biol. Chem. 273, 20721-20727. https://doi.org/10.1074/jbc.273.33.20721 (1998).

35. Le, Y., Tan, S. M., Lee, S. H., Kon, O. L. \& Lu, J. Purification and binding properties of a human ficolin-like protein. J. Immunol. Methods 204, 43-49. https://doi.org/10.1016/s0022-1759(97)00029-x (1997).

36. Adler Sorensen, C., Rosbjerg, A., Hebbelstrup Jensen, B., Krogfelt, K. A. \& Garred, P. The lectin complement pathway is involved in protection against enteroaggregative Escherichia coli infection. Front. Immunol. 9, 1153. https://doi.org/10.3389/fimmu.2018.01153 (2018).

37. Lee, R. T. \& Lee, Y. C. Affinity enhancement by multivalent lectin-carbohydrate interaction. Glycoconj. J. 17, 543-551. https://doi. org/10.1023/a:1011070425430 (2000).

38. Sacchettini, J. C., Baum, L. G. \& Brewer, C. F. Multivalent protein-carbohydrate interactions. A new paradigm for supermolecular assembly and signal transduction. Biochemistry 40, 3009-3015. https://doi.org/10.1021/bi002544j (2001).

39. Kiessling, L. L., Young, T., Gruber, T. D. \& Mortell, K. H. In Glycoscience: Chemistry and Chemical Biology (eds Fraser-Reid, B. O. et al.) 2483-2523 (Springer, Berlin, 2008)

40. Tran, B. N. et al. Higher order structures of Adalimumab, Infliximab and their complexes with TNFalpha revealed by electron microscopy. Protein Sci. 26, 2392-2398. https://doi.org/10.1002/pro.3306 (2017).

41. Tang, G. et al. EMAN2: An extensible image processing suite for electron microscopy. J. Struct. Biol. 157, 38-46. https://doi. org/10.1016/j.jsb.2006.05.009 (2007).

42. Grant, T., Rohou, A. \& Grigorieff, N. cisTEM, user-friendly software for single-particle image processing. eLife https://doi. org/10.7554/eLife.35383 (2018).

43. Fornstedt, N. \& Porath, J. Characterization studies on a new lectin found in seeds of Vicia ervilia. FEBS Lett. 57, 187-191. https:// doi.org/10.1016/0014-5793(75)80713-7 (1975).

44. Waterhouse, A. et al. SWISS-MODEL: Homology modelling of protein structures and complexes. Nucleic Acids Res. 46, W296-w303. https://doi.org/10.1093/nar/gky427 (2018).

\section{Acknowledgements}

This work is supported by the Thailand Research Fund and Office of the Higher Education Commission, Ministry of Education Research Grant for New Scholar number MRG6180012 (KW). This work is also partially supported by the Chulalongkorn University grant to the Center of Excellence for Molecular Biology and Genomics of Shrimp (KW and AT) and Molecular Crop Research Unit (KW). NS and KW is supported by the Second Century Fund (C2F), Chulalongkorn University. We would like to thank Prof. Alisa Vangnai for the use of microscope and camera, and DKSH (Thailand) Limited for access to a dynamic light scattering equipment.

\section{Author contributions}

K.W. and A.T. designed the study and analyzed the results. K.W. and S.L. performed protein expression. K.W. and N.S. purified the protein, examined the biochemical properties, performed ligand binding, bacteria binding, and agglutination assays. K.W. acquired light scattering data. B.N.T., K.W. and P.T.M. acquired the electron microscopy data. K.W. wrote the manuscript with input from other authors.

\section{Competing interests}

The authors declare no competing interests.

\section{Additional information}

Supplementary Information The online version contains supplementary material available at https://doi. org/10.1038/s41598-021-82301-5.

Correspondence and requests for materials should be addressed to K.W.

Reprints and permissions information is available at www.nature.com/reprints.

Publisher's note Springer Nature remains neutral with regard to jurisdictional claims in published maps and institutional affiliations.

(c) (i) Open Access This article is licensed under a Creative Commons Attribution 4.0 International License, which permits use, sharing, adaptation, distribution and reproduction in any medium or format, as long as you give appropriate credit to the original author(s) and the source, provide a link to the Creative Commons licence, and indicate if changes were made. The images or other third party material in this article are included in the article's Creative Commons licence, unless indicated otherwise in a credit line to the material. If material is not included in the article's Creative Commons licence and your intended use is not permitted by statutory regulation or exceeds the permitted use, you will need to obtain permission directly from the copyright holder. To view a copy of this licence, visit http://creativecommons.org/licenses/by/4.0/.

(C) The Author(s) 2021 